Proceedings of the 18th National Conference on Superconductivity, Krynica Morska, Poland, October 8-13, 2017

\title{
Synthesis and Physicochemical Properties of $\mathrm{Er}_{0.5} \mathrm{Dy}_{0.5} \mathrm{Ba}_{2} \mathrm{Cu}_{3} \mathrm{O}_{6.83}$ \\ Cuprate High-Temperature Superconductor
}

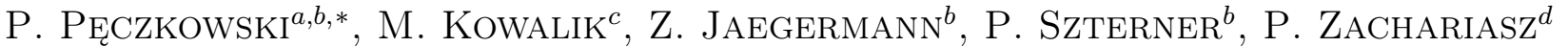 \\ AND W.M. WOCH ${ }^{c}$ \\ ${ }^{a}$ Cardinal Stefan Wyszyński University, Faculty of Mathematics and Natural Sciences. School of Exact Sciences, \\ Department of Physics, K. Wóycickiego 1/3, 01-938 Warsaw, Poland \\ ${ }^{b}$ Institute of Ceramics and Building Materials, Department of Ceramic Technology, \\ Postępu 9, 02-676 Warsaw, Poland \\ ${ }^{c}$ AGH University of Science and Technology, Faculty of Physics and Computer Science, \\ Department of Solid State Physics, al. A. Mickiewicza 30, 30-059 Cracow, Poland \\ ${ }^{d}$ Institute of Electron Technology, Department of Microelectronics, Zabłocie 39, 30-701 Cracow, Poland
}

The aim of this research was an analysis of physicochemical properties of a ceramic high-temperature superconductor $\mathrm{Er}_{0.5} \mathrm{Dy}_{0.5} \mathrm{Ba}_{2} \mathrm{Cu}_{3} \mathrm{O}_{6.83}$. Qualitative and quantitative phase analysis of the raw material sintering and annealing in oxygen atmosphere was performed by method of X-ray diffraction. The structural analysis revealed that the high-temperature superconductors mainly crystalize in orthorhombic phase with small traces of $\mathrm{BaCuO}_{2}$ and $\mathrm{CuO}$. Local microstructure analysis was carried out by scanning electron microscopy. The thermogravimetric and differential thermal analysis show that in addition to the presence of the main phase, other phases are also observed. Critical temperatures $T_{c 0}$ and $T_{c}$, critical current density $J_{c}$ and superconducting transition width $\Delta T$ were evaluated from resistance and AC susceptibility measurements.

DOI: 10.12693/APhysPolA.135.28

PACS/topics: 74.25.-q, 74.25.Bt, 74.25.Sv, 74.72.-h

\section{Introduction}

In a numerous group of superconductors, one can distinguish the low-temperature superconductors (LTS), where superconductivity state exists below $30 \mathrm{~K}$, and the high-temperature superconductors (HTS) having critical temperature above $30 \mathrm{~K}$. Over the last 30 years many materials belonging to the high-temperature superconductors group have been discovered [1-7]. They are of great interest because of their electrical and magnetic properties and their practical applicability [8-10].

So far, many studies have been focused on the properties of superconducting ceramic $\mathrm{YBa}_{2} \mathrm{Cu}_{3} \mathrm{O}_{7-x}$ (YBCO). In recent years, many articles were published describing the properties of $\mathrm{REBa}_{2} \mathrm{Cu}_{3} \mathrm{O}_{7-x}$, materials in which yttrium $(\mathrm{Y})$ were replaced by other rare earth elements, in particular Er, Ho, Dy, Gd, Eu, Sm, Nd, La or their combinations [11-14]. Among other, the research is focused on the resistivity of these compounds in function of temperature [11] and the impact of high-pressure treatment on conductivity and critical temperature $[15,16]$.

In the article by Kumar-Naik et al. [17], the authors analyzed the structural properties of materials $\mathrm{REBa}_{2} \mathrm{Cu}_{3} \mathrm{O}_{7-x} \quad \mathrm{RE}=\mathrm{Gd}, \mathrm{Sm}, \mathrm{Nd}$ in equal proportion) in function of the infiltration growth process.

*corresponding author; e-mail: p.peczkowski@wp.pl
Fetisov et al. [18] discussed the thermal and spectroscopic results of $\mathrm{DyBa}_{2} \mathrm{Cu}_{3} \mathrm{O}_{7-x}$. The motivation of these studies was to analyse the results of Murugesan et al. [19] showing higher stability towards corrosion of DyBa $\mathrm{Cu}_{3} \mathrm{O}_{7-x}$ relative to $\mathrm{YBa}_{2} \mathrm{Cu}_{3} \mathrm{O}_{7-x}$.

The physical properties of the ceramic superconductors mainly depend on the synthesis methods and the technological aspects used for preparing the raw materials [20-22]. A large effort is aimed for reducing the costs and time of producing a material with the relevant properties. In present study a superconducting material $\mathrm{Er}_{0.5} \mathrm{Dy}_{0.5} \mathrm{Ba}_{2} \mathrm{Cu}_{3} \mathrm{O}_{7-x}$ was fabricated by a solid state reaction method and its physicochemical properties were compared with the reference $\mathrm{YBa}_{2} \mathrm{Cu}_{3} \mathrm{O}_{7-x}$ sample $[23,24]$. The Er and Dy atoms were selected due to the similarity of the effective ionic radii for $\mathrm{Er}^{3+}$ $(89.0 \mathrm{pm})$ and $\mathrm{Dy}^{3+}(91.2 \mathrm{pm})$, whose average value $90.1 \mathrm{pm}$ is close to that of $\mathrm{Y}^{3+}(90.0 \mathrm{pm})[24,25]$.

\section{Experimental}

\subsection{Synthesis procedure}

For material synthesis, we used Sigma Aldrich substrates of erbium(III) oxide $-\mathrm{Er}_{2} \mathrm{O}_{3}$, dysprosium(III) oxide - $\mathrm{Dy}_{2} \mathrm{O}_{3}$ (both with $99.99 \%$ purity), $\mathrm{POCH}$ barium carbonate - $\mathrm{BaCO}_{3}$ with purity of $99.6 \%$, and Alfa Aesar copper(II) oxide - $\mathrm{CuO}$ with purity of $99.999 \%$.

After weighing the substrates in an appropriate amounts the mixture of powders was milled with isopropanol in a ratio of 1:1. After drying, the powder was 
twice sintered in order to perform a solid state reaction. After each sintering step, the sinter was ground in a mortar. The both sintering step were carried out in air atmosphere in an electric muffle furnace according to the temperature profile shown in Fig. 1.

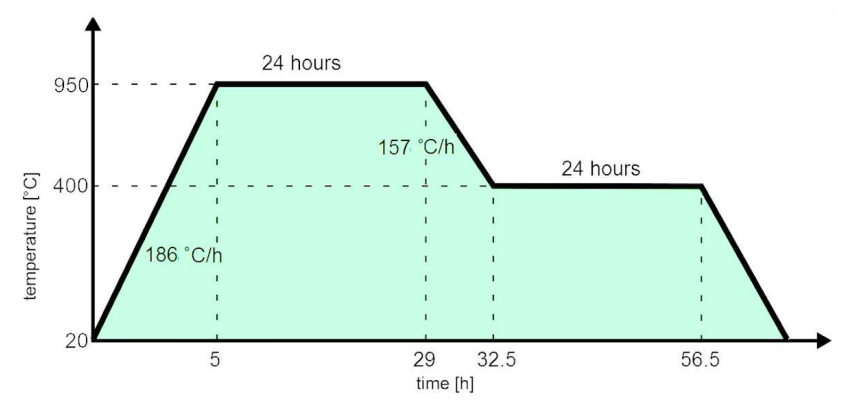

Fig. 1. Temperature profile of sintering steps for $\mathrm{REBa}_{2} \mathrm{Cu}_{3} \mathrm{O}_{7-x}$.

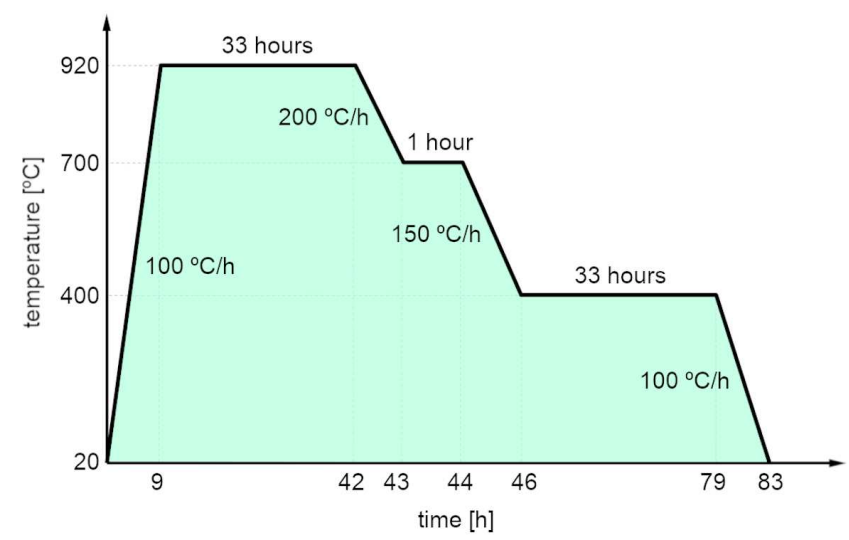

Fig. 2. Temperature profile of annealing in oxygen atmosphere for $\mathrm{REBa}_{2} \mathrm{Cu}_{3} \mathrm{O}_{7-x}[26]$.

The samples were formed into pellets of $12 \mathrm{~mm}$ in diameter and $1.5 \mathrm{~mm}$ thick by uniaxial pressing at $800 \mathrm{MPa}$. The annealing were made in the oxygen atmosphere (flow of $20 \mathrm{l} / \mathrm{h}$ ) according to the temperature profile presented in Fig. 2.

\subsection{Characterization}

X-ray diffraction measurements of the sinters after the sintering and annealing steps were made by Brucker AXS D8 Discaver, where quantitative measurements were carried out by means of the Rietveld analysis in Topas software.

Sample morphology and local microstructure analysis were performed by using the FEI Nova NANOSEM 2000 field emission electron microscope equipped with the ETD (Everhart-Thornley detector).

The zero field cooling (ZFC) dispersion $\chi^{\prime}$ and absorption $\chi^{\prime \prime}$ parts of AC susceptibility were measured as a function of temperature and $H_{\mathrm{AC}}$ magnetic field amplitudes ranging from 0.022 Oe to 10.9 Oe by a standard mutual inductance bridge operating at the frequency of $189 \mathrm{~Hz}$. A Stanford Research System SR830 DSP lockin amplifier served both as a source for the AC current for the coil producing the AC magnetic field and as a voltmeter of the bridge. The applied magnetic field $H_{\mathrm{AC}}$ was parallel to the surface plane of the rectangular prism cut from the pellet. The temperature was monitored by the Lake Shore Model 330 autotuning temperature controller with chromel-gold $-0.07 \% \mathrm{Fe}$ thermocouple of $0.3 \mathrm{~K}$ accuracy and resolution of $0.05 \mathrm{~K}$. The above apparatus was also used in measurements of the resistance vs. temperature by the four-point method.

\section{Results and discussion}

The microscopic images of the milled raw powders show that the rare earth oxide grains $\left(\mathrm{Er}_{2} \mathrm{O}_{3}, \mathrm{Dy}_{2} \mathrm{O}_{3}\right)$ have various shapes and are cracked, the barium carbonate $\left(\mathrm{BaCO}_{3}\right)$ grains are oriented in one direction, while the copper oxide $(\mathrm{CuO})$ grains create highly porous agglomerates (Fig. 3).

The highest average apparent density were reached for $\operatorname{Er}_{0.5} \mathrm{Dy}_{0.5} \mathrm{Ba}_{2} \mathrm{Cu}_{3} \mathrm{O}_{7-x}$ sample before annealing in oxygen atmosphere $(6.31 \pm 0.15) \mathrm{g} / \mathrm{cm}^{3}$ and after annealing $(5.62 \pm 0.06) \mathrm{g} / \mathrm{cm}^{3}$. For comparison, the average density of $\mathrm{YBa}_{2} \mathrm{Cu}_{3} \mathrm{O}_{7-x}$ were $(5.25 \pm 0.09) \mathrm{g} / \mathrm{cm}^{3}$ and $(4.89 \pm 0.06) \mathrm{g} / \mathrm{cm}^{3}$ before and after annealing, respectively.

The local microstructures of all superconductors are similar. The SEM images show the presence of large grains and areas containing smaller, well-sintered grains.

Qualitative and quantitative powder phase analysis was performed with X-ray diffraction (XRD) method. Accuracy of the method was about 1\%. In Tables I and II are presented the results of the crystalline phase content of the individual samples.

The X-ray analysis showed that after the second sintering, the amount of the superconducting phase $\mathrm{REBa}_{2} \mathrm{Cu}_{3} \mathrm{O}_{7-x}$ was increased, while the contributions of $\mathrm{BaCuO}_{2}, \mathrm{BaCO}_{3}, \mathrm{CuO}$, and $\mathrm{RE}_{2} \mathrm{BaCuO}_{5}$ were decreased. For $\mathrm{DyBa}_{2} \mathrm{Cu}_{3} \mathrm{O}_{7-x}$ and $\mathrm{Er}_{0.5} \mathrm{Dy}_{0.5} \mathrm{Ba}_{2} \mathrm{Cu}_{3} \mathrm{O}_{7-x}$ the $\mathrm{BaCO}_{3}$ crystalline phase disappears after the second sintering (Table I).

The oxygen factor $x=0.17$ in crystalline phase $\mathrm{REBa}_{2} \mathrm{Cu}_{3} \mathrm{O}_{6.83}$ were calculated by Rietveld method based on published crystalline structures (COD and PDF +2014 , including ICSD).

The phase analysis after annealing in an oxygen atmosphere showed that the orthorhombic $\mathrm{REBa}_{2} \mathrm{Cu}_{3} \mathrm{O}_{6.83}$ is a major phase, and only small contributions of $\mathrm{BaCuO}_{2}$ and $\mathrm{CuO}$ were identified in the samples (Table II). SEM of the $\mathrm{REBa}_{2} \mathrm{Cu}_{3} \mathrm{O}_{6.83}$ samples microstructure are shown in Fig. 4.

In the case of ideally mixed precursors only onefold sintering should be sufficient to obtain single-phase $\mathrm{REBa}_{2} \mathrm{Cu}_{3} \mathrm{O}_{7-x}$ sample. Nevertheless, in a real technological process the number of obtained crystalline phases depends on how well the precursors were mixed. As one can follow the results shown in Table I and 

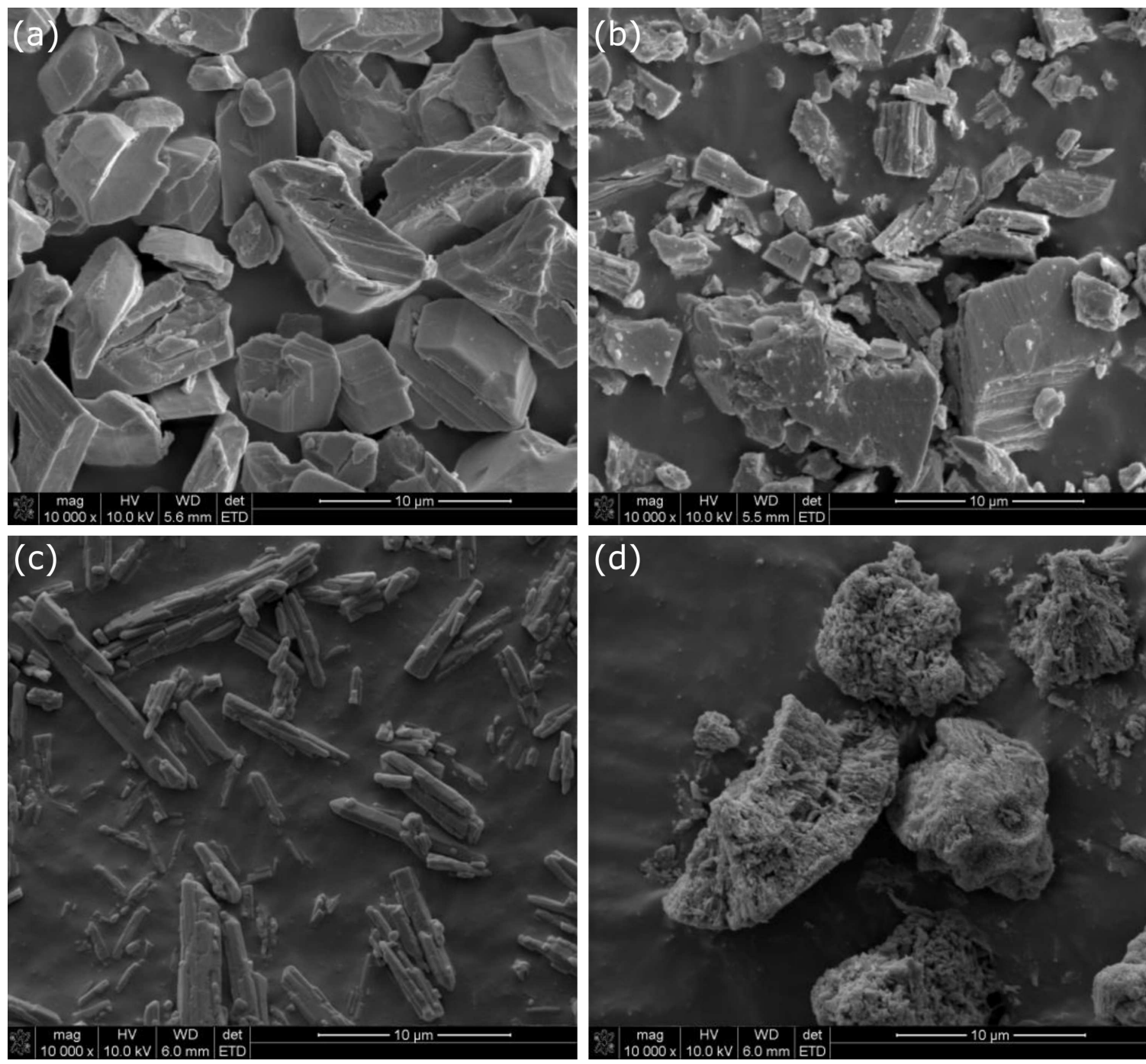

Fig. 3. SEM images of raw powders used for the preparation of REBCO with ETD detector (magnification: $10000 \times$ ): (a) $\mathrm{Er}_{2} \mathrm{O}_{3}$, (b) $\mathrm{Dy}_{2} \mathrm{O}_{3}$, (c) $\mathrm{BaCO}_{3}$, (d) $\mathrm{CuO}$.

TABLE I

Crystalline phase contents of $\mathrm{ErBa}_{2} \mathrm{Cu}_{3} \mathrm{O}_{7-x}, \mathrm{DyBa}_{2} \mathrm{Cu}_{3} \mathrm{O}_{7-x}, \mathrm{Er}_{0.5} \mathrm{Dy}_{0.5} \mathrm{Ba}_{2} \mathrm{Cu}_{3} \mathrm{O}_{7-x}, \mathrm{YBa}_{2} \mathrm{Cu}_{3} \mathrm{O}_{7-x}$ after first and second sintering

\begin{tabular}{l|c|c|c|c}
\hline \hline \multirow{2}{*}{ Crystalline phase } & \multicolumn{4}{|c}{ Phase content [wt. \%] } \\
\cline { 2 - 5 } & $\mathrm{ErBa}_{2} \mathrm{Cu}_{3} \mathrm{O}_{7-x}$ & $\mathrm{DyBa}_{2} \mathrm{Cu}_{3} \mathrm{O}_{7-x}$ & $\mathrm{Er}_{0.5} \mathrm{Dy}_{0.5} \mathrm{Ba}_{2} \mathrm{Cu}_{3} \mathrm{O}_{7-x}$ & $\mathrm{YBa}_{2} \mathrm{Cu}_{3} \mathrm{O}_{7-x}$ \\
\hline \multicolumn{5}{|c}{ After first sintering } \\
\hline $\mathrm{REBa}_{2} \mathrm{Cu}_{3} \mathrm{O}_{7-x}{ }^{a}$ & $60.7 \pm 0.7$ & $72.2 \pm 0.7$ & $79.6 \pm 0.5$ & $70.7 \pm 0.5$ \\
$\mathrm{BaCuO}_{2}$ & $15.7 \pm 0.3$ & $4.9 \pm 0.3$ & $4.4 \pm 0.2$ & $8.1 \pm 0.2$ \\
$\mathrm{BaCO}_{3}$ & $3.9 \pm 0.3$ & $1.5 \pm 0.3$ & $2.6 \pm 0.3$ & $5.7 \pm 0.2$ \\
$\mathrm{CuO}$ & $9.6 \pm 0.5$ & $10.6 \pm 0.4$ & $5.4 \pm 0.3$ & $7.2 \pm 0.3$ \\
$\mathrm{RE}_{2} \mathrm{BaCuO}_{5}$ & $10.1 \pm 0.2$ & $10.8 \pm 0.2$ & $8.0 \pm 0.2$ & $8.3 \pm 0.2$ \\
\hline \multicolumn{5}{l}{ After second sintering } \\
\hline $\mathrm{REBa}_{2} \mathrm{Cu}_{3} \mathrm{O}_{7-x}{ }^{a}$ & $74.7 \pm 0.6$ & $79.9 \pm 0.7$ & $89.5 \pm 0.5$ & $6.1 \pm 0.3$ \\
$\mathrm{BaCuO}_{2}$ & $7.6 \pm 0.2$ & $4.0 \pm 0.3$ & $3.0 \pm 0.3$ & $2.9 \pm 0.3$ \\
$\mathrm{BaCO}_{3}$ & $1.6 \pm 0.2$ & - & - & $4.1 \pm 0.3$ \\
$\mathrm{CuO}_{\mathrm{RE}} \mathrm{BaCuO}_{5}$ & $8.4 \pm 0.3$ & $10.5 \pm 0.4$ & $3.4 \pm 0.3$ & $4.9 \pm 0.2$ \\
\hline
\end{tabular}

${ }^{a} \mathrm{RE}=\mathrm{Er}, \mathrm{Dy}, \mathrm{Er}_{0.5} \mathrm{Dy}_{0.5}, \mathrm{Y}$ 
TABLE II

Results of Rietveld analysis of $\mathrm{ErBa}_{2} \mathrm{Cu}_{3} \mathrm{O}_{6.83}, \mathrm{DyBa}_{2} \mathrm{Cu}_{3} \mathrm{O}_{6.83}, \mathrm{Er}_{0.5} \mathrm{Dy}_{0.5} \mathrm{Ba}_{2} \mathrm{Cu}_{3} \mathrm{O}_{6.83}, \mathrm{YBa}_{2} \mathrm{Cu}_{3} \mathrm{O}_{6.83}$, samples after annealing in oxygen atmosphere

\begin{tabular}{l|c|c|c|c}
\hline \hline \multirow{2}{*}{ Crystalline phase } & \multicolumn{4}{|c}{ Phase content [wt. \%] } \\
\cline { 2 - 5 } & $\mathrm{ErBa}_{2} \mathrm{Cu}_{3} \mathrm{O}_{6.83}$ & $\mathrm{DyBa}_{2} \mathrm{Cu}_{3} \mathrm{O}_{6.83}$ & $\mathrm{Er}_{0.5} \mathrm{Dy}_{0.5} \mathrm{Ba}_{2} \mathrm{Cu}_{3} \mathrm{O}_{6.83}$ & $\mathrm{YBa}_{2} \mathrm{Cu}_{3} \mathrm{O}_{6.83}$ \\
\hline $\mathrm{REBa}_{2} \mathrm{Cu}_{3} \mathrm{O}_{6.83}{ }^{a}$ & $91.3 \pm 0.8$ & $92.1 \pm 0.7$ & $98.1 \pm 0.5$ & $92.4 \pm 0.5$ \\
$\mathrm{BaCuO}_{2}$ & $3.3 \pm 0.3$ & $3.8 \pm 0.2$ & $0.9 \pm 0.1$ & $5.1 \pm 0.2$ \\
$\mathrm{CuO}$ & $5.5 \pm 0.3$ & $4.1 \pm 0.4$ & $1.0 \pm 0.2$ & $2.4 \pm 0.2$ \\
\hline
\end{tabular}

${ }^{a} \mathrm{RE}=$ Er, Dy, $\operatorname{Er}_{0.5} \mathrm{Dy}_{0.5}, \mathrm{Y}$
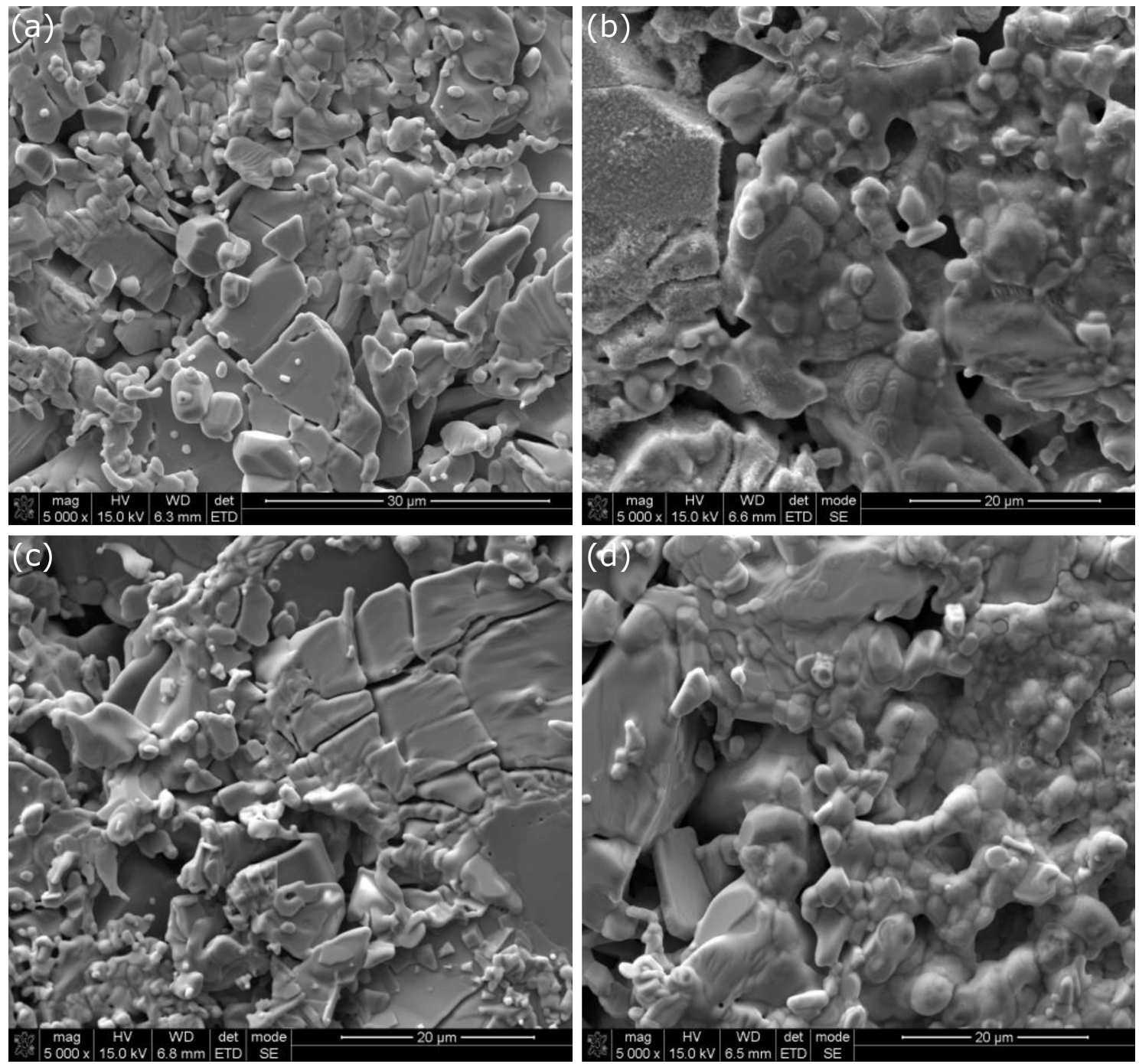

Fig. 4. SEM images of $\mathrm{REBa}_{2} \mathrm{Cu}_{3} \mathrm{O}_{6.83}$ microstructure with ETD detector (magnification: 5000x):

(a) $\mathrm{Er}_{0.5} \mathrm{Dy}_{0.5} \mathrm{Ba}_{2} \mathrm{Cu}_{3} \mathrm{O}_{6.83}$, (b) $\mathrm{ErBa}_{2} \mathrm{Cu}_{3} \mathrm{O}_{7-x}$, (c) $\mathrm{DyBa}_{2} \mathrm{Cu}_{3} \mathrm{O}_{6.83}$, (d) $\mathrm{YBa}_{2} \mathrm{Cu}_{3} \mathrm{O}_{6.83}$.

Table II, the percentage quantity of superconducting crystalline phase $\mathrm{REBa}_{2} \mathrm{Cu}_{3} \mathrm{O}_{7-x}$ increases with increasing number of the steps of milling followed by high-temperature annealing. The quantity of nonsuperconducting crystalline phases decreases. The extra mixing/grinding steps allow the minor phases to take part in solid state reaction, which results in creation of more superconducting crystalline phase $\mathrm{REBa}_{2} \mathrm{Cu}_{3} \mathrm{O}_{7-x}$. $\mathrm{Er}_{0.5} \mathrm{Dy}_{0.5} \mathrm{Ba}_{2} \mathrm{Cu}_{3} \mathrm{O}_{6.83}(0.9 \pm 0.1) \mathrm{wt} \%$ but lower than for
After annealing in oxygen atmosphere, the highest amount of superconducting phase $\mathrm{REBa}_{2} \mathrm{Cu}_{3} \mathrm{O}_{6.83}$ was found to be $(98.1 \pm 0.5)$ wt $\%$ in the mixed $\mathrm{Er}_{0.5} \mathrm{Dy}_{0.5} \mathrm{Ba}_{2} \mathrm{Cu}_{3} \mathrm{O}_{6.83}$ sample, and the smallest amount of $(91.3 \pm 0.8)$ wt\% in sample $\mathrm{ErBa}_{2} \mathrm{Cu}_{3} \mathrm{O}_{6.83}$. The $\mathrm{BaCuO}_{2}$ content of about $(3.3 \div 3.8)$ wt $\%$ in the $\mathrm{ErBa}_{2} \mathrm{Cu}_{3} \mathrm{O}_{6.83}$ and $\mathrm{DyBa}_{2} \mathrm{Cu}_{3} \mathrm{O}_{6.83}$ ceramics is significantly higher than that for the mixed sample $\mathrm{YBa}_{2} \mathrm{Cu}_{3} \mathrm{O}_{6.83}(5.1 \pm 0.2)$ wt\%. Also, $\mathrm{CuO}$ contributions 


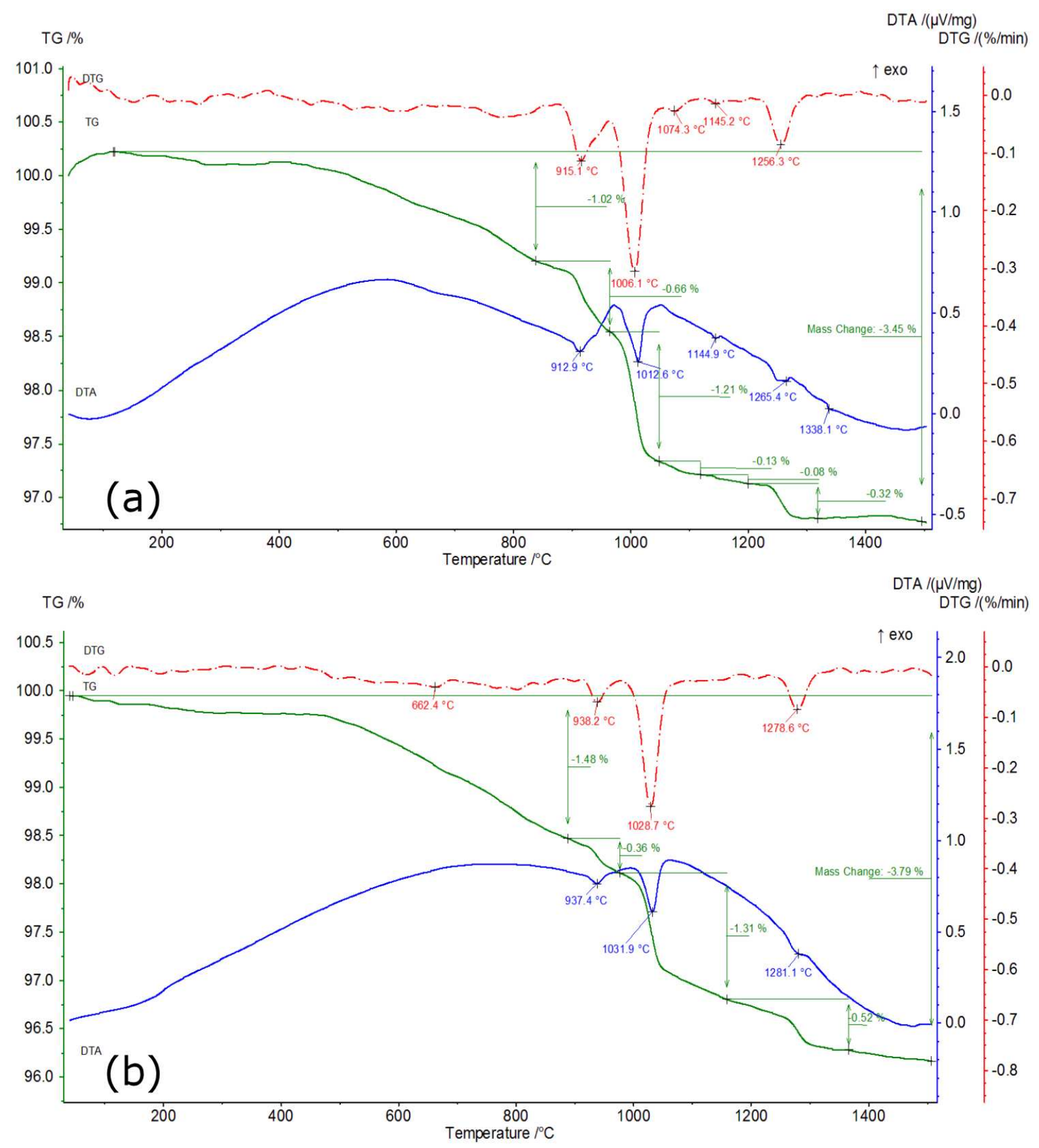

Fig. 5. The TG/DTA for $\mathrm{Er}_{0.5} \mathrm{Dy}_{0.5} \mathrm{Ba}_{2} \mathrm{Cu}_{3} \mathrm{O}_{7-x}$ : (a) in air atmosphere after the first sintering, (b) in oxygen atmosphere after the second sintering.

in $\mathrm{ErBa}_{2} \mathrm{Cu}_{3} \mathrm{O}_{6.83}(5.5 \pm 0.3) \mathrm{wt} \%$ and $\mathrm{DyBa}_{2} \mathrm{Cu}_{3} \mathrm{O}_{6.83}$ $(4.1 \pm 0.4)$ wt $\%$ are significantly higher than for the mixed sample $\operatorname{Er}_{0.5} \mathrm{Dy}_{0.5} \mathrm{Ba}_{2} \mathrm{Cu}_{3} \mathrm{O}_{6.83}(1.0 \pm 0.2) \mathrm{wt} \%$.

The unit cell parameters for orthorhombic phase $\mathrm{REBa}_{2} \mathrm{Cu}_{3} \mathrm{O}_{6.83}$ were determined by the Rietveld analysis of the XRD patterns (Table III).

The unit cell parameters for orthorhombic phase $\mathrm{YBa}_{2} \mathrm{Cu}_{3} \mathrm{O}_{6.83}$ are very similar to the parameters of $\mathrm{Er}_{0.5} \mathrm{Dy}_{0.5} \mathrm{Ba}_{2} \mathrm{Cu}_{3} \mathrm{O}_{6.83}$. The volume of the unit cell for orthorhombic phase depends on the radius
TABLE III

The unit cell parameters for orthorhombic phase $\mathrm{REBa}_{2} \mathrm{Cu}_{3} \mathrm{O}_{6.83}$

\begin{tabular}{l|c|c|c|c|c}
\hline \hline \multicolumn{1}{c|}{ Superconductor } & $\begin{array}{c}a \\
{[\mathrm{~nm}]}\end{array}$ & $\begin{array}{c}b \\
{[\mathrm{~nm}]}\end{array}$ & $\begin{array}{c}c \\
{[\mathrm{~nm}]}\end{array}$ & $\begin{array}{c}V \\
{\left[\mathrm{~nm}^{3}\right]}\end{array}$ & $\begin{array}{c}\rho \\
{\left[\mathrm{g} / \mathrm{cm}^{3}\right]}\end{array}$ \\
\hline $\mathrm{ErBa}_{2} \mathrm{Cu}_{3} \mathrm{O}_{6.83}$ & 0.3826 & 0.3880 & 1.1671 & 0.1733 & 7.123 \\
$\mathrm{DyBa}_{2} \mathrm{Cu}_{3} \mathrm{O}_{6.83}$ & 0.3850 & 0.3878 & 1.1682 & 0.1744 & 7.030 \\
$\mathrm{Er}_{0.5} \mathrm{Dy}_{0.5} \mathrm{Ba}_{2} \mathrm{Cu}_{3} \mathrm{O}_{6.83}$ & 0.3830 & 0.3884 & 1.1674 & 0.1737 & 7.084 \\
$\mathrm{YBa}_{2} \mathrm{Cu}_{3} \mathrm{O}_{6.83}$ & 0.3831 & 0.3882 & 1.1675 & 0.1736 & 6.350
\end{tabular}


of the $\mathrm{RE}^{3+}$ ion. The mean radius of the ions $\mathrm{Er}^{3+}$ and $\mathrm{Dy}^{3+}$ is similar to the radius of the $\mathrm{Y}^{3+}$, therefore the unit cell volumes for orthorhombic phase are comparable $[24,25]$.

Since the main purpose of this work was to characterize the superconductor $\mathrm{Er}_{0.5} \mathrm{Dy}_{0.5} \mathrm{Ba}_{2} \mathrm{Cu}_{3} \mathrm{O}_{7-x}$, the results of thermal and magnetic investigations of this material were only included in the article.

The results of the thermogravimetric-differential thermal analysis (TG-DTA) carried out in air atmosphere after the first and second sintering for $\mathrm{Er}_{0.5} \mathrm{Dy}_{0.5} \mathrm{Ba}_{2} \mathrm{Cu}_{3} \mathrm{O}_{7-x}$ are shown in Fig. 5. One can see the characteristic temperatures of endothermic reactions, where a formation of $\mathrm{Er}_{0.5} \mathrm{Dy}_{0.5} \mathrm{Ba}_{2} \mathrm{Cu}_{3} \mathrm{O}_{7-x}$ phase take place around $912.9^{\circ} \mathrm{C}$ and about $937.4^{\circ} \mathrm{C}$ after the first and the second sintering, respectively. On the other hand, the peritectic reactions associated with the decomposition of $\mathrm{Er}_{0.5} \mathrm{Dy}_{0.5} \mathrm{Ba}_{2} \mathrm{Cu}_{2} \mathrm{O}_{7-x}$ to $\mathrm{Er}_{0.5} \mathrm{Dy}_{0.5} \mathrm{Ba}_{2} \mathrm{Cu}_{2} \mathrm{O}_{5}, \mathrm{Ba}_{2} \mathrm{Cu}_{2} \mathrm{O}_{5}$ and $\mathrm{BaCuO}_{2}$ are characteristic around $1012.6{ }^{\circ} \mathrm{C}$ and $1031.9^{\circ} \mathrm{C}$ after the first and second sintering. Also, the thermograms show that, in addition to the main $\mathrm{Er}_{0.5} \mathrm{Dy}_{0.5} \mathrm{Ba}_{2} \mathrm{Cu}_{2} \mathrm{O}_{5}$ phase, the other phases contribution to the additional effects are observed on the DTA curves $[27,28]$.

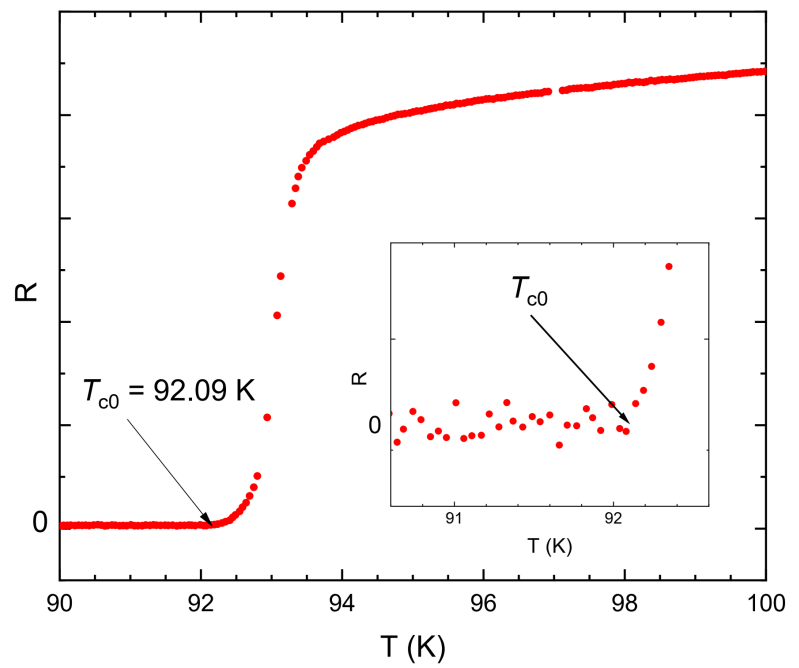

Fig. 6. Temperature dependence of the resistance of $\mathrm{Er}_{0.5} \mathrm{Dy}_{0.5} \mathrm{Ba}_{2} \mathrm{Cu}_{3} \mathrm{O}_{6.83}$.

The temperature dependence of the resistance of $\mathrm{Er}_{0.5} \mathrm{Dy}_{0.5} \mathrm{Ba}_{2} \mathrm{Cu}_{3} \mathrm{O}_{6.83}$ is shown in Fig. 6. The sample exhibits critical temperature $T_{c 0}=(92.09 \pm 0.30) \mathrm{K}$ and narrow superconducting transition $\Delta T=(0.69 \pm 0.05) \mathrm{K}$. The definitions of $T_{c 0}$ and $\Delta T$ are as in [29]. For comparison, the $\mathrm{DyBa}_{2} \mathrm{Cu}_{3} \mathrm{O}_{6.83}$ sample studied in [30] has the critical temperature $T_{c}=(91.40 \pm 0.10) \mathrm{K}$ and $\Delta T=(0.70 \pm 0.10) \mathrm{K}$. Moreover, the round-shaped $\mathrm{Er}_{0.5} \mathrm{Dy}_{0.5} \mathrm{Ba}_{2} \mathrm{Cu}_{3} \mathrm{O}_{6.83}$ pellet of thickness $3 \mathrm{~mm}$ and $12 \mathrm{~mm}$ in diameter exhibits a specific resistance about $(3.30 \pm 0.15) \mathrm{m} \Omega \mathrm{cm}$, which was determined at room temperature using the van der Pauw method [31, 32].
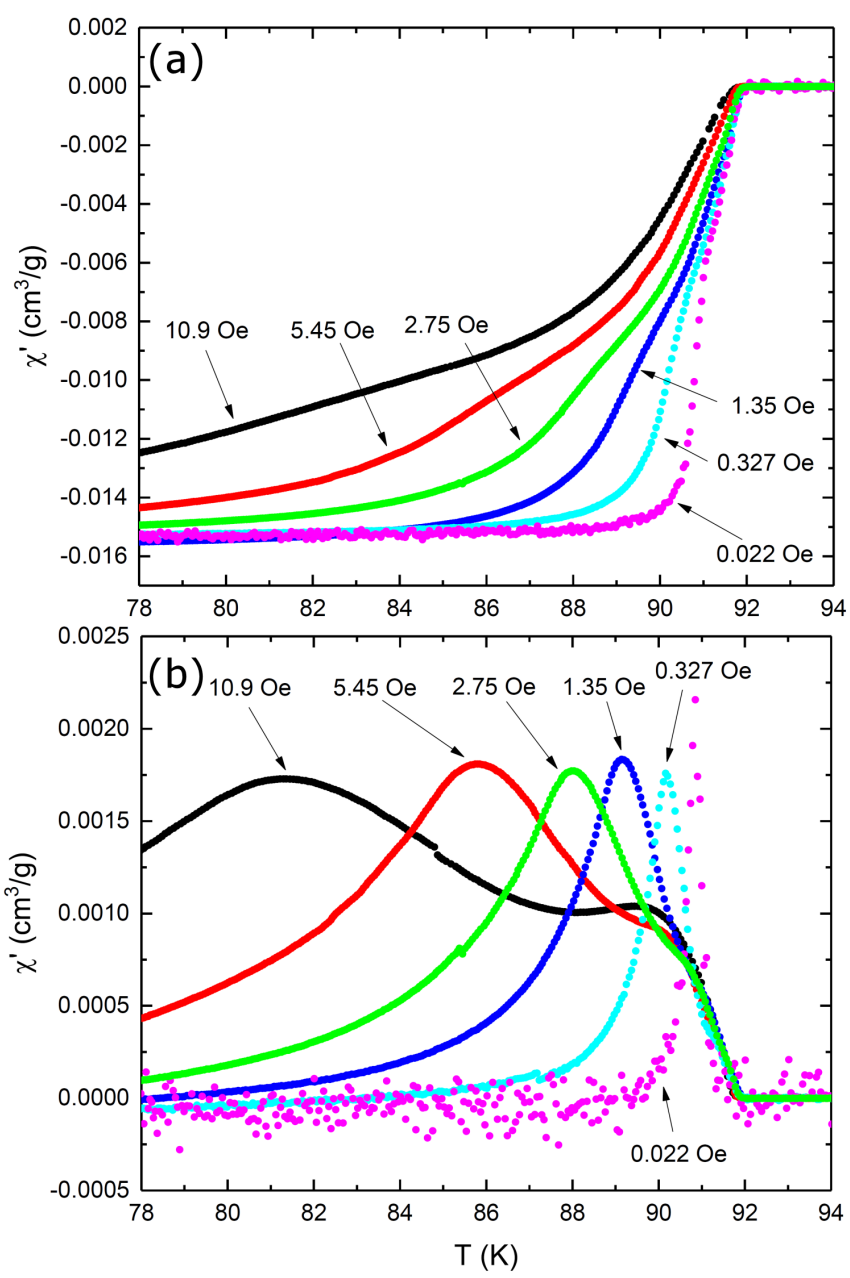

Fig. 7. The real (a) and imaginary (b) parts of the AC susceptibility for $\mathrm{Er}_{0.5} \mathrm{Dy}_{0.5} \mathrm{Ba}_{2} \mathrm{Cu}_{3} \mathrm{O}_{6.83}$ in function of temperature and applied magnetic field.

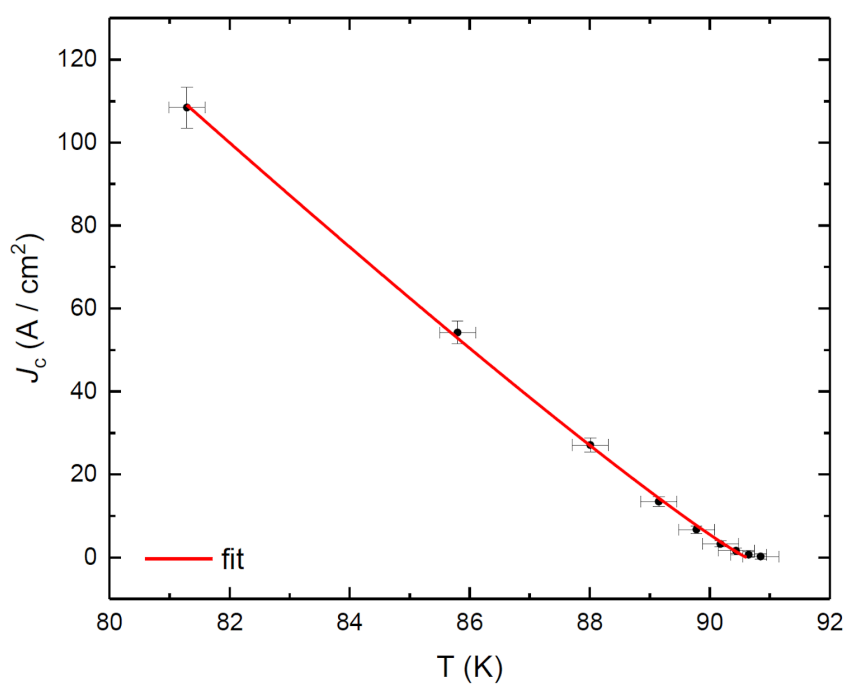

Fig. 8. The critical current density vs. temperature for $\mathrm{Er}_{0.5} \mathrm{Dy}_{0.5} \mathrm{Ba}_{2} \mathrm{Cu}_{3} \mathrm{O}_{6.83}$ calculated from the Bean critical state model (Eq. (1)). The solid line is the fit to Eq. (2). 
The ZFC dispersion $\chi^{\prime}$ and absorption $\chi^{\prime \prime}$ parts of $\mathrm{AC}$ susceptibility are show in Fig. 7. The intra-grain critical temperature $T_{c}=(92.10 \pm 0.30) \mathrm{K}$ was determined from the dispersion part of AC susceptibility. The $T_{c}$ was defined as the temperature corresponding to the last negative value of $\chi^{\prime}$ when the temperature of the sample was increasing. The temperature dependences of the absorption part of AC susceptibility at different magnetic fields $H_{A C}$ were measured in order to evaluate the critical current density $J_{c}$. In general, the absorption part of the AC susceptibility exhibits one peak associated with the energy losses related to the magnetic field penetration at grain boundary regions. In the case of the studied sample the absorption peak associated with the energy losses in grains was also observed. The former peak is located at lower temperatures than the latter. When the applied magnetic field $H_{\mathrm{AC}}$ is being increased, the intergrain peak moves faster to the lower temperatures than the intra-grain peak. According to the Bean critical state model the position of the absorption peak on the temperature axis is related to the critical current density $J_{c}$ with formula (1) [33, 34]:

$$
J_{c}=2 H_{A C} / d \text {, }
$$

where $H_{A C}$ is the AC field amplitude and $d$ is the sample thickness in the direction perpendicular to the magnetic field $H_{A C}$. The critical current flows through the grains and inter-grain regions. The critical current density is limited by the weakest junctions (i.e. intergrain regions) on the percolation path of the current. The calculated intergrain critical current densities $J_{c}$ are presented in Fig. 8. According to the Ginzburg-Landau strong coupling limit approach, the critical current density varies with temperature according to the following equation [35]:

$$
J_{c}=J_{c 0}\left(1-T / T_{c J}\right)^{n},
$$

where $T_{c J}$ is the critical temperature of intergrain regions and $J_{c 0}$ is the intergrain critical current density at $0 \mathrm{~K}$.

Figure 8 shows the temperature dependence of the critical current density fitted by Eq. (2), where the $T_{c J}, J_{c 0}$ and $n$ are fit parameters. The value of critical current density $J_{c}$ at $77 \mathrm{~K}$ is about $(165 \pm 30) \mathrm{A} \mathrm{cm}^{-2}$ and is typical for bulk RE-123 HTS samples (where RE rare-earth element) with large grains and weak intergrain links. The values of fitted parameters are $T_{c J}=(90.61 \pm 0.12) \mathrm{K}$, $J_{c 0}=(1318 \pm 171) \mathrm{A} \mathrm{cm}^{-2}$ and $n=1.096 \pm 0.056$.

\section{Conclusion}

The article describes a method of preparing the ceramic high-temperature superconductors based on the rare-earth elements $\mathrm{RE}=\mathrm{Er}$, Dy, Y. The materials were obtained by solid state reaction method followed by grinding, sintering, and annealing of the mixture of powders in oxygen atmosphere at high-temperature. Structural studies have confirmed that the orthorhombic phase is responsible for high-temperature superconductivity, and the $\mathrm{Er}_{0.5} \mathrm{Dy}_{0.5} \mathrm{Ba}_{2} \mathrm{Cu}_{3} \mathrm{O}_{6.83}$ sample contains of about $98 \%$ of the superconducting phase.
Critical temperatures $T_{c 0}$ and $T_{c}$, critical current density $J_{c}$ and superconducting transition width $\Delta T$ of $\mathrm{Er}_{0.5} \mathrm{Dy}_{0.5} \mathrm{Ba}_{2} \mathrm{Cu}_{3} \mathrm{O}_{6.83}$ were evaluated from resistance and $\mathrm{AC}$ susceptibility vs. temperature measurements. The values of critical temperatures were $T_{c}=(92.10 \pm$ $0.30) \mathrm{K}$ and $\Delta T=(0.70 \pm 0.10) \mathrm{K}, T_{c 0}=(92.09 \pm 0.30) \mathrm{K}$ and $\Delta T=(0.70 \pm 0.10) \mathrm{K}$. Critical current density $J_{c}=(165 \pm 30) \mathrm{A} \mathrm{cm}^{-2}$ at liquid nitrogen temperature was calculated using the Bean critical state model and the Ginzburg-Landau strong coupling limit approach.

\section{Acknowledgments}

Authors would like to thank S. Kobyakov for his useful discussions.

Part of this work was supported by the AGH UST statutory tasks No. 11.11.220.01/6 within subsidy of the Ministry of Science and Higher Education.

\section{References}

[1] M.K. Wu, J.R. Ashburn, C.J. Torng, P.H. Hor, R.L. Meng, L. Gao, Z.J. Huang, Y.Q. Wang, C.W. Chu, Phys. Rev. Lett. 58, 908 (1987).

[2] H. Maeda, Y. Tanaka, M. Fukutomi, T. Asano, Jpn. J. Appl. Phys. 27, L209 (1988).

[3] Z.Z. Sheng, A.M. Hermann, Nature 332, 55 (1988).

[4] J. Karpinski, E. Kaldis, E. Jilek, S. Rusiecki, B. Bucher, Nature 336, 660 (1988).

[5] S.N. Putilin, E.V. Antipov, O. Chmaissem, M. Marezio, Nature 362, 226 (1993).

[6] T. Kawashima, Y. Matsui, E. Takayama-Muromachi, Physica C 224, 69 (1994).

[7] J. Schwartz, K.M. Amm, Y.R. Sun, C. Wolters, Physica B 216, 261 (1996).

[8] C.W. Chu, P.H. Hor, R.L. Meng, L. Gao, Z.J. Huang, Y.Q. Wang, Phys. Rev. Lett. 58, 911 (1987).

[9] P. Paturi, J. Raittila, J.C. Grivel, H. Huhtinen, B. Seifi, R. Laiho, N.H. Andersen, Physica C 372376, 779 (2002).

[10] K. Onabe, T. Doi, N. Kashima, S. Nagaya, T. Saitoh, Physica C 378-381, 907 (2002).

[11] H.C. Yang, M.H. Hsieh, H.H. Sung, C.H. Chen, H.E. Horng, Y.S. Kan, H.C. Chen, J.C. Jao, Phys. Rev. B 39, 9203 (1989).

[12] S.J. Jin, R.A. Fastnacht, T.H. Tiefel, R.C. Sherwood, Phys. Rev. B 37, 5828 (1988).

[13] A. Salinas-Sanchez, J.L. Garcia-Muñoz, J. RodriguezCarvajal, R. Saez-Puche, J.L. Martinez, J. Solid State Chem. 100, 201 (1992).

[14] P. Pęczkowski, M. Kowalik, P. Zachariasz, C. Jastrzębski, Z. Jaegermann, P. Szterner, W.M. Woch, J. Szczytko, Phys. Status Solidi A 215, 1700888 (2018).

[15] K. Al-Shibani, A. Al-Aql, A. Al-Muezzin, H. Humeida, E.P. Nakhmedov, T. Firat, O. Öztürk, Ö.A. Sacli, Phys. Status Solidi B 189, 177 (1995).

[16] P. Peczkowski, P. Szterner, Z. Jaegermann, M. Kowalik, R. Zalecki, W.M. Woch, J. Supercond. Nov. Magn. 31, 2719 (2018). 
[17] S.P. Kumar-Naik, V.S. Bai, Cryogenics 81, 47 (2017).

[18] A.V. Fetisov, G.A. Kozhina, S.K. Estemirova, V.B. Fetisov, R.I. Gulyaeva, Physica $C$ 508, 62 (2015).

[19] M. Murugesan, H. Obara, Y. Nakagawa, H. Yamasaki, Y. Mawatari, S. Kosaka, Appl. Phys. Lett. 88, 252509 (2006).

[20] P. Pęczkowski, P. Szterner, Z. Jaegermann, Sci. Works Instit. Ceram. Build. Mater. 27, 57 (2016).

[21] P. Szterner, P. Pęczkowski, Z. Jaegermann, Sci. Works Instit. Ceram. Build. Mater. 28, 62 (2017).

[22] P. Szterner, P. Pęczkowski, Z. Jaegermann, Sci. Works Instit. Ceram. Build. Mater. 29, 48, 61 (2017).

[23] M.K. Wu, J.R. Ashburn, C.J. Torng, P.H. Hor, R.L. Meng, L. Gao, Z.J. Huang, Y.Q. Wang, C.W. Chu, Phys. Rev. Lett. 58, 908 (1987).

[24] C. Andreouli, A. Tsetsekou, J. Eur. Ceramic. Soc. 20, 2101 (2000).
[25] Y. Xu, W. Guan, Physica C 212, 119 (1993).

[26] S. Alagöz, Tur. J. Phys. 33, 69 (2009).

[27] J. Plewa, H. Altenburg, J. Hauck, Therm. Acta 255, 177 (1995).

[28] R. Redac, M. Zaharescu, J. Therm. Anal. Calor. 66, 513 (2001).

[29] W.M. Woch, R. Zalecki, A. Kołodziejczyk, O. Heiml, G. Gritzner, Physica C 434, 17 (2006).

[30] A. Kołodziejczyk, A. Kozłowski, J. Chmist, R. Zalecki, T. Sciężor, Z. Tarnawski, W.M. Woch, Acta Phys. Pol. A 84, 127 (1993).

[31] L.J. Van der Pauw, Philips Tech. Rev. 20, 220 (1958).

[32] L.J. Van der Pauw, Philips Res. Rep. 13, 1 (1958).

[33] C.P. Bean, Phys. Rev. Lett. 8, 250 (1962).

[34] J.R. Clem, Physica C 153-155, 50 (1988).

[35] J.R. Clem, B. Bumble, S.I. Raider, W.J. Gallagher, Y.C. Shih, Phys. Rev. B 35, 6637 (1987). 